\title{
Influential Factors on Pro-Environmental Behaviors- A Case Study in Tokyo and Seoul
}

\author{
Hyunsook Lee ${ }^{1}$, Kiyo Kurisu ${ }^{2}$, Keisuke Hanaki ${ }^{1}$ \\ ${ }^{1}$ Department of Urban Engineering, Graduate School of Engineering, The University of Tokyo, Tokyo, Japan; ${ }^{2}$ Research Center for \\ Advanced Science and Technology, The University of Tokyo, Tokyo, Japan. \\ Email: hslee@ir3s.u-tokyo.ac.jp, kiyo@env.t.u-tokyo.ac.jp, hanaki@env.t.u-tokyo.ac.jp
}

Received July 23 ${ }^{\text {rd }}$, 2013; revised August $23^{\text {rd }}$, 2013; accepted September $1^{\text {st }}, 2013$

Copyright (C) 2013 Hyunsook Lee et al. This is an open access article distributed under the Creative Commons Attribution License, which permits unrestricted use, distribution, and reproduction in any medium, provided the original work is properly cited.

\begin{abstract}
To develop the low-carbon society, in addition to the efforts by industrial and commercial sectors, promotion of people's pro-environmental behaviors (PEBs) has become one of the key issues. Some PEBs have been investigated in previous studies, however, the targets were limited to particular behaviors (i.e., recycling, water saving, electricity saving). The holistic view of understanding the characteristics of PEBs has remained insufficient. In this study, we selected 58 daily PEBs from various fields and investigated people's practice rates and attitudes in Seoul and Tokyo. The questionnaire surveys were conducted and 2393 (Seoul) and 2220 (Tokyo) valid responses were analyzed. Most PEBs had significantly different practice rates between Seoul and Tokyo. It can be concluded that the surrounding conditions, such as policy and infrastructure, have some influences on these differences. The positions of the reasons to practice or not to practice PEBs were visualized using multiple correspondence analyses. The results indicated that the monetary reason was the common factor for many PEBs, while some PEBs showed different reasons. The socio-demographic effects were not significantly different between the two regions. Commonly, women and older people showed more activities on PEBs.
\end{abstract}

Keywords: Pro-Environmental Behaviors; Practice Rate; Multiple Correspondence Analysis; Reason for Behavior

\section{Introduction}

The promotion of pro-environmental behaviors (PEBs) in people's daily lives is one of the key issues in developing sustainable societies. According to the national census for environmental conservation [1], more than $80 \%$ of people in South Korea express great environmental concerns. The Korean Ministry of Environment started the "Green Start Movement” in 2008 and has intensively promoted people's PEBs through campaigns, video clips, and leaflet distributions. In 2009, the Korean government established "Low Carbon Green Growth," and the "Presidential Committee on Green Growth" to achieve a 30\% reduction in greenhouse gas emission by 2020. The "Carbon Cashbag" and "Carbon Footprint" programs were started in response. The "Carbon Cashbag" program offers various low-carbon products, and people who buy these products are reimbursed with shopping-points. Similar to programs in many other countries, the "Carbon Footprint" program shows the lifetime carbon dioxide emission of a product. These programs can enhance people's environmental awareness.
Even if people have a high awareness of environmental issues, there are many internal and external barriers to taking actual action [2-3]. Although people may intend to practice PEBs, various factors such as traditional values, lifestyle, and surrounding circumstances can influence their behavior. In the field of PEB studies, to understand the PEBs deeply, various cross-national studies have been conducted [4-9].

Previous studies have also paid much attention to methods for enhancing PEBs and environmental awareness. Many studies are found in the fields of recycling [10-14], electricity saving [15-19], and water saving behaviors [20-22]. However, each study mainly focuses on one particular PEB, and studies comprehensively dealing with various PEBs are rarely found. In response to the lack of the holistic understandings of PEBs, this study deals with various PEBs and discusses their characteristics through comparison of Seoul and Tokyo citizens. Seoul is the capital of the Republic of Korea, with an area of $605 \mathrm{~km}^{2}$ and a population of 10.5 million.

Tokyo is the capital of Japan, and its central 23 wards, 
with an area of $622 \mathrm{~km}^{2}$ and a population of 8.7 million, form the target area for this study. Although these cities are geographically close (about $1150 \mathrm{~km}$ apart) in the Asian region, we assume that differences in citizens' behavioral patterns arise from different internal and external reasons.

This paper aims to reveal the characteristics of various PEBs through a questionnaire survey. It will particularly focus on the practice rate of each PEB, people's reasons to practice or not practice the behavior, and the effect of socio-demographics.

\section{Material and Methods}

\subsection{Questionnaire Design}

To achieve the research aims, we decided to use an online questionnaire survey. In this type of survey, people who register via a web research company are requested to fill out a questionnaire, and points are given to correspond to their answers. More general respondents can be obtained through this online method, as the respondents with higher intension tend to be willing to mail back in the case of conventional postal questionnaires. The quality of registered respondents is also controlled by the web research company. This online method is suitable for conducting a large-scale questionnaire surveys and for obtaining a quick and high response rate. The questionnaire design and analysis of the obtained raw data attribute to a researcher.

The questionnaire consisted of three parts: 1 ) practice rates of PEBs, 2) reasons to practice or not to practice each PEB, and 3) socio-demographics.

We selected 58 daily PEBs (Table 1) based on the previous selection by Aoki et al. [23], which was based on the behaviors recommended by the national and local governments and environmental NPOs in Japan. In addition to Aoki et al.'s selection, we added or subtracted several behaviors considering the circumstances of each city. For example, "B49: Carbon Cashbag" is a program that only exists in Korea, and therefore this behavior was removed from the list used in Tokyo. Hence, 56 and 52 PEBs were selected for use in Seoul and Tokyo respectively, with 50 PEBs common to both cities. Each respondent's practice rate was measured using the 4-point Likert Scale: "always," "often," "rarely,” and "never." Regarding behaviors that require that the respondents have access to certain equipment, such as "B10: Personal computer," "B13: Bidet," "B55: Dishwasher," and behaviors relating to cars (B34-B38), respondents were first asked whether they had the equipment, and respondents who did own the equipment then answered the questions. In part 2, 11 reasons to practice and 13 reasons not to practice PEBs were presented to the respondent as shown in Table 2. Respondents who answered "always" or "of- ten” in Part 1 were asked the reasons why they practiced the behavior, and respondents who answered "rarely" or "never" were asked the reasons why they did not practice the behavior. The respondents chose their primary and secondary reasons for practicing or not practicing the behavior from the list of reasons for each PEB.

Part 3 asked for details of socio-demographics, such as gender, age, occupation, and income.

\subsection{Survey and Analysis}

The surveys were conducted by EZ Survey Co. in Seoul from November 2 to 10, 2010, and by Nikkei Research Co. in Tokyo from February 1 to 13, 2011. The questionnaire was completed by men and women aged 20 50 in Seoul and 10 - 70 in Tokyo. The obtained sample numbers were 5546 and 3489, respectively.

When comparing the results of the two cities, the age and gender distributions should fit the distributions of the parent populations. Therefore, respondents aged 20 - 50 years were randomly extracted from the respondents to fit the distributions recorded in the 2010 National Censuses of both cities. Finally, 2393 and 2220 respondents were used for analysis in Seoul and Tokyo respectively. Data analysis was performed using SPSS 18.0 (IBM co., USA).

\section{Results and Discussion}

\subsection{Practice Rates of PEBs}

The practice rate of each PEB was defined as the percentage of answers that were "always" or "often."

A practice rate of more than $50 \%$ was observed in 42 out of the 56 PEBs in Seoul and 37 out of the 52 PEBs in Tokyo. In Seoul, the behaviors with high practice rates were "B58: Outdoor incineration" and "B24: Waste disposal by the rules," whereas low rates were observed for "B29: Composting" and "B5: Using stairs." Similarly, in Tokyo, B24 had a high practice rate and B29 had a low rate. While these trends were found in both cities, a difference in the PEB practice rate was also found. For example, "B29: Composting" had similarly low practice rates in Seoul and Tokyo when compared to other PEBs, but the practice rates found in Seoul (21.1\%) and in Tokyo (7.0\%) were quite different.

To check the significance of the difference between Seoul and Tokyo, the answers were coded on a scale from 4 (for "always") to 1 (for "never"), and statistical tests were conducted. According to the normality test, no behaviors showed normal distributions, and therefore the Mann-Whitney test, one of the non-parametric tests corresponding to the t-test, was adopted. Figure 1 shows the results. In Seoul and Tokyo, 44 out of 50 PEBs showed significantly different practice scores $(p<0.05)$. 
Table 1. Targeted pro-environmental behaviors.

\begin{tabular}{|c|c|c|c|}
\hline Behavior number & Pro-environmental behavior & Short description & \\
\hline B1 & Avoiding overloading the refrigerator & Refrigerator (overloaded) & \\
\hline B2 & Reducing opening and closing the door of the refrigerator & Refrigerator (door) & \\
\hline B3 & Using a lower setting in the refrigerator compartment & Refrigerator (temperature) & \\
\hline B4 & Putting hot food into refrigerator after cooling & Refrigerator (cooling) & \\
\hline B5 & Using stairs instead of elevators & Elevator & \\
\hline B6 & Cleaning filter of air conditioner or cleaner & Filter cleaning & \\
\hline B7 & Turning off lights in empty rooms & Light off & \\
\hline B8 & Unplugging appliances not in use & Power (plug) & \\
\hline B9 & Turning off the TV when people are not watching & Power (TV) & \\
\hline B10 & Using energy saving mode or turning off when not in use & Power (monitor) & \\
\hline B11 & Adjusting the temperature of the air conditioner or radiator & Ideal temperature (air conditioner) & \\
\hline B12 & Setting a lower shower temperature & Ideal temperature (shower) & \\
\hline B13 & Adjusting the temperature of the bidet seat and water or closing the lid & Ideal temperature (bidet) & \\
\hline B14 & Doing ironing collectively & Iron & \\
\hline B15 & Using toothbrush cup & Water saving (teeth brush cup) & * \\
\hline B16 & Turning off the water when washing face & Water saving (wash face) & * \\
\hline B17 & Taking short showers & Water saving (shower) & \\
\hline B18 & Putting plastic bottles or stones into the toilet water tank & Water saving (bidet) & \\
\hline B19 & Washing dishes using jugged water & Water saving (dish wash) & \\
\hline B20 & Turning off the water when washing face or brushing teeth & Water saving (teeth brush) & + \\
\hline B21 & Cutting down on the frequency of washing clothes & Laundry & \\
\hline B22 & Avoiding throwing away waste cooking oil & Used cooking oil & \\
\hline B23 & Reducing detergent & Little detergent & \\
\hline B24 & Following garbage rules & Waste (rule) & \\
\hline B25 & Recycling milk packs or newspapers & Recycle (newspaper) & \\
\hline B26 & Giving used clothes to other people or using a recycle box & Recycle (second-hand clothes) & \\
\hline B27 & Using own cup & My cup & \\
\hline B28 & Avoiding over-volume cooking & Proper cooking & \\
\hline B29 & Composting kitchen garbage & Food waste (compost) & \\
\hline B30 & Throwing away kitchen garbage after it has dried & Food waste (dehydration) & \\
\hline B31 & Using receptacle instead of plastic bag & Reuse (airtight container) & \\
\hline B32 & Using both sides of paper & Reuse (paper) & \\
\hline B33 & Reducing use of disposable products & Disposable goods & \\
\hline B34 & Joining the one day without car program & Car (one day without car) & * \\
\hline B35 & Doing car checks regularly & Car (checking) & \\
\hline B36 & Avoiding overloading the car & Car (overloading) & \\
\hline B37 & Reducing idling of car & Car (idling) & \\
\hline B38 & Maintaining air pressure of tire & Car (tire pressure) & \\
\hline B39 & Using bicycle or walking & Bicycle or Walking & \\
\hline B40 & Using public transportation & Public transportation & \\
\hline B41 & Buying eco-appliances & Eco-appliance & \\
\hline
\end{tabular}




\begin{tabular}{ccc} 
Continued & Buying ecomark-appliances & \\
\hline B42 & Buying recycled goods & Ecomark-appliance \\
B43 & Not buying unnecessary products & Recying goods \\
B44 & Trying to repair things before buying replacements & Repair \\
B45 & Using refill goods & Refillable goods \\
B46 & Buying organic products & Organic goods \\
B47 & Choosing goods with their CO ${ }_{2}$ emission in mind (carbon footprint) \\
B48 & Buying carbon cashbag products & Carbon footprint \\
B49 & Trying to buy a hybrid car if necessary & Carbon cashbag \\
B50 & Using own bag when going shopping & Eco-Car \\
B51 & Not buying over-packaged products & My Bag \\
B52 & Using LED lamp instead of fluorescent lamp & Little package \\
B53 & Turning off air conditioner/heater in empty rooms & Using LED \\
B54 & Using dish washer & Temperature control off \\
B55 & Flame adjustment for cooking & Dishwasher \\
B56 & Using curtain for cutting heat & Eco-cooking \\
B57 & Not burning the trash in the yard & Insulation \\
B58 & & Incinerate at the outdoor \\
\hline
\end{tabular}

${ }^{*}$ Only in Seoul; ${ }^{+}$Only in Japan.

Table 2. Conduct/not conduct reasons.

\begin{tabular}{cc}
\hline Conduct reasons & Not conduct reasons \\
\hline Rule & Bothersome \\
Habit & Time consuming \\
Saving & Inconvenience \\
Environment friendly & Not environment friendly \\
Friend & Cost \\
Moral & No consideration \\
Cool & Forget \\
Healthful & Nobody doing \\
Others & No recognition \\
Convenience & No chance \\
Getting points & No necessity \\
& No rule \\
& Not cool (only in Japan) \\
\hline
\end{tabular}

\subsection{Possible Factors Causing the Practice Rate Difference}

\subsubsection{Influence of Surrounding Conditions}

Cultural difference is one of the reasons for the difference in practice rates between the two cities.

For instance, the practice rate of "B54: Temperature control off" was significantly higher $(p<0.000)$ in Tokyo (3.48) than in Seoul (3.02). In Korea, traditional "Ondol" floor-heating is well-established as the system for controlling the temperature of a house. Since this is a central-heating system, people must go to a boiler room to control the room temperature. On the contrary, it is common in Japan for each room to have an individual temperature control system. Therefore, Japanese people can control the room temperature more easily than Korean people. This is reflected in the higher practice rate of B54 in Tokyo than in Seoul. Cultural difference is a fundamental factor and cannot be easily changed by external forces. However, other external factors, such as policies and infrastructure, can be controlled to enhance PEBs. The practice rate of "B26: Recycling second-hand clothes" was significantly higher $(p<0.001)$ in Seoul (3.20) than in Tokyo (2.19). In Tokyo, when people want to recycle their old clothes, they need bring their clothes to collection places like schools and department stores where local governments or apparel makers collect old clothes. On the other hand, in Seoul, the local government consigns old-clothes collection to private organizations, and collection boxes are placed beside daily curbside waste collection boxes (Figure 2). The higher practice rate of B26 in Seoul can be attributed to this difference.

The effect of policy can also be seen for other PEBs such as "B29: Composting" and "B51: My own bag." Seoul respondents had a significantly higher $(p<0.000)$ practice score (1.89) for composting behavior (B29) than people in Tokyo (1.29). In 1998, the Korean government put the "Basic Plan for Recycling Food Waste (19982002)" into force and banned the disposal of food waste 


\begin{tabular}{|c|c|c|c|c|c|c|c|c|c|c|c|c|c|c|c|c|c|}
\hline \multirow{2}{*}{$\begin{array}{c}\text { Behavior } \\
\text { No. } \\
\end{array}$} & \multirow{2}{*}{ Short description } & \multicolumn{2}{|c|}{ Mann-Whitney } & & & \multirow{2}{*}{ Average $^{b}$} & & \multirow{2}{*}{ S.D ${ }^{c}$} & \multirow{2}{*}{$\begin{array}{c}\text { Behavior } \\
\text { No. }\end{array}$} & \multirow{2}{*}{ Short description } & \multicolumn{3}{|c|}{ Mann-Whitney } & & \multirow{2}{*}{ Average $^{b}$} & \multirow{2}{*}{\multicolumn{2}{|c|}{ S.D }} \\
\hline & & $\mathbf{U}$ & $\mathbf{p}$ & & & & & & & & $\mathbf{U}$ & p & & & & & \\
\hline \multirow{2}{*}{ B1 } & \multirow{2}{*}{ Refrigerator (overloaded) } & \multirow{2}{*}{1821720.5} & \multirow{2}{*}{.000} & $* * *$ & $\mathrm{~S}$ & & 2.45 & .72 & $B 29$ & Fond waste (conmost) & 12612045 & 000 & $* * *$ & $\mathrm{~S}$ & & 1.89 & 1.83 \\
\hline & & & & & $\mathrm{T}$ & & 2.80 & .84 & B29 & Food waste (compost) & 1261224.5 & .000 & & $\mathrm{~T}$ & & 1.29 & .66 \\
\hline B2 & Refrigerator (door) & 2108009.0 & .000 & $* * *$ & S & & 2.58 & .71 & $B 30$ & Food waste (debydration) & 21736095 & 009 & $* *$ & S & & 2.72 & .82 \\
\hline & & 2100009.0 & & & $\mathrm{~T}$ & & 2.84 & .81 & B30 & Food waste (deny dration) & $21 / 3609.5$ & & wa & $\mathrm{T}$ & & 2.63 & .97 \\
\hline B3 & Refrigerator (temperature) & 2254456.0 & 000 & *** & $\mathrm{s}$ & & 2.36 & .78 & $B 31$ & Reuse (airtight container) & 14340870 & 000 & $* * *$ & S & & 3.03 & .70 \\
\hline & & & & & $\mathrm{T}$ & & 2.48 & .97 & BO31 & Reuse (airtignt contanner) & $143408 / .0$ & .000 & & $\mathrm{~T}$ & & 2.37 & .90 \\
\hline $\mathrm{PA}$ & Refrior & 23002915 & 090 & $* *$ & $\mathrm{~s}$ & & 3.13 & .82 & $\mathrm{~B} 23$ & $\mathrm{Be}_{\mathrm{e}}$ & 23511105 & 000 & $* * *$ & $\mathrm{~s}$ & & 3.07 & .68 \\
\hline B4 & Kerrigerator (cooming) & 2300291.5 & .000 & & $\mathrm{~T}$ & & 3.21 & .88 & B32 & Reuse (paper) & 2351110.5 & .000 & & $\mathrm{~T}$ & & 2.86 & .96 \\
\hline B5 & Using stair & 2460126.5 & .008 & $* *$ & $\mathrm{~s}$ & & 2.06 & .81 & B33 & Disposable goods & 2073331.0 & .000 & $* * *$ & S & & 2.90 & .65 \\
\hline & & & & & $\mathrm{T}$ & & 2.15 & .91 & & & & & & $\mathrm{~T}$ & & 2.59 & .83 \\
\hline$B 6$ & Filter cleannig & 22825285 & 000 & *** & $\mathrm{s}$ & & 2.45 & .77 & $B 35$ & Car(checking) & 4735110 & 000 & *** & $\mathrm{s}$ & & 2.97 & .74 \\
\hline Do & 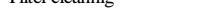 & 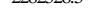 & .000 & & $\mathrm{~T}$ & & 2.36 & .84 & w & 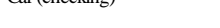 & $4 / 011.0$ & & & $\mathrm{~T}$ & & 2.53 & .88 \\
\hline B7 & Light off & 2482578.0 & .000 & $* * *$ & $\mathrm{~s}$ & & 3.35 & .69 & B36 & Car (overloading) & 2018156.5 & .258 & & $\mathrm{~s}$ & & 2.89 & .73 \\
\hline & & & & & $\mathrm{T}$ & & 3.40 & .75 & & & & & & $\mathrm{~T}$ & & 2.84 & .89 \\
\hline B8 & Power (plug) & 2205625.5 & .000 & *** & S & & 2.59 & .89 & B37 & Car(idling) & 6000855 & 000 & $* * *$ & S & & 3.06 & .65 \\
\hline & rower (pitig) & & & & $\mathrm{T}$ & & 2.34 & .96 & DI & Car (Iung) & 年 & .000 & & $\mathrm{~T}$ & & 3.17 & .79 \\
\hline $\mathrm{BO}$ & Powor (TTY & 23166900 & 090 & $* * *$ & $\mathrm{~s}$ & & 3.10 & .85 & 839 & ( & 6471645 & 280 & & $\mathrm{~s}$ & & 3.01 & .64 \\
\hline BY & Power(IV) & 2310000.0 & .000 & & $\mathrm{~T}$ & & 2.90 & .95 & D38 & Car (III) pressure) & $64 / 164.5$ & .280 & & $\mathrm{~T}$ & & 2.97 & .83 \\
\hline B10 & Power (monitor) & 2584587.0 & .494 & & $\mathrm{~S}$ & & 3.18 & .79 & B39 & Bicycle or Waking & 694021.5 & .000 & $* * *$ & $\mathrm{~s}$ & & 3.07 & .73 \\
\hline DIV & Power (III)IItur) & $230400 / .0$ & .434 & & $\mathrm{~T}$ & & 3.14 & .92 & DOS & Dicycie or vraking & $0340 \angle 1 . J$ & (.000 & & $\mathrm{T}$ & & 3.36 & .78 \\
\hline B11 & Ideal temperature & 18797985 & 000 & $* * *$ & $\mathrm{~S}$ & & 2.85 & .70 & $B 40$ & Public transportation & 23683920 & 000 & $* * *$ & $\mathrm{~S}$ & & 3.22 & .76 \\
\hline & (air conditioner) & & & & $\mathrm{T}$ & & 3.18 & .84 & & 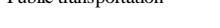 & & & & $\mathrm{T}$ & & 3.32 & .85 \\
\hline B12 & Ideal temperature (shower) & 1357503.0 & 000 & $* * *$ & $\mathrm{~s}$ & & 2.94 & .64 & B41 & Fco-Appliance & 18934045 & 000 & $* * *$ & $\mathrm{~s}$ & & 2.97 & .68 \\
\hline & & $135 / 503.0$ & .000 & and & $\mathrm{T}$ & & 2.20 & .88 & B41 & Eco-Appllance & 1893444.5 & .000 & Fats & $\mathrm{T}$ & & 2.59 & .89 \\
\hline B13 & Ideal temperature (bidet) & 612389.5 & .000 & $* * *$ & S & & 2.73 & .80 & B43 & Recycling goods & 20554840 & 000 & $* * *$ & $\mathrm{~s}$ & & 2.48 & .71 \\
\hline DID & 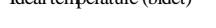 & & & & $\mathrm{T}$ & & 3.17 & .92 & Dis & Necycing govous & $2000+0+0$ & .000 & & $\mathrm{~T}$ & & 2.20 & .79 \\
\hline B14 & Jon & 15070970 & 090 & $* * *$ & $\mathrm{~s}$ & & 2.89 & .79 & $\mathrm{B} P \mathrm{~A}$ & Nhod bec rods mid onco & 25742130 & 716 & & $\mathrm{~s}$ & & 2.94 & .62 \\
\hline B14 & Iron & $158 / 98 / .0$ & .000 & $w_{n}=$ & $\mathrm{T}$ & & 3.07 & .95 & B44 & Neediess goods avoliance & $25 / 4343.0$ & .146 & & $\mathrm{~T}$ & & 2.92 & .74 \\
\hline B17 & Water saving (shower) & 25198245 & 005 & ** & $\mathrm{s}$ & & 2.71 & .77 & $B 45$ & Benair & 23764635 & 000 & $* * *$ & $\mathrm{~S}$ & & 3.07 & .59 \\
\hline $\mathrm{D} 17$ & Water saving (snower) & 2519034.5 & . 025 & and & $\mathrm{T}$ & & 2.66 & .90 & B45 & Kepalr & $23 / 0403.5$ & . & a & $\mathrm{T}$ & & 2.95 & .71 \\
\hline B18 & Water saving (bidet) & 1428280.5 & 000 & *** & $\mathrm{S}$ & & 2.13 & 1.00 & $B 46$ & Refillabble ooods & 19788875 & 000 & $* * *$ & S & & 2.97 & .65 \\
\hline & water saving (otact) & & .000 & & $\mathrm{~T}$ & & 1.47 & .88 & $D+0$ & Neimavie govas & (3) & .000 & & $\mathrm{~T}$ & & 3.26 & .67 \\
\hline B19 & Water saving (dish wash) & 2131505.5 & .000 & $* * *$ & S & & 2.09 & .84 & B47 & Organic goods & 1648949.0 & .000 & $* * *$ & $\mathrm{~S}$ & & 2.51 & .73 \\
\hline & & & & & $\mathrm{T}$ & & 2.01 & .98 & & & & & & $\mathrm{~T}$ & & 2.03 & .79 \\
\hline B21 & Laundry & 2162507.5 & .000 & $* * *$ & S & & 3.28 & .66 & $B 50$ & Eco-Car & 17492600 & 373 & & S & & 2.33 & .79 \\
\hline & & $210200 \%$ & & 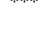 & $\mathrm{T}$ & & 3.32 & .76 & $\mathrm{BSO}$ & ECO-Lar & & $.3 / 3$ & & $\mathrm{~T}$ & & 2.33 & 1.01 \\
\hline$B 22$ & Used cookino oil & 21996980 & 479 & & $\mathrm{~S}$ & & 2.97 & .78 & $B 51$ & My Bag & 21220370 & 000 & ** & $\mathrm{s}$ & & 3.13 & .79 \\
\hline B 22 & Used cooking OII & 2199098.0 & $.4 / 9$ & & $\mathrm{~T}$ & & 2.91 & 1.01 & BOS & My Bag & 2122033.0 & .000 & 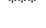 & $\mathrm{T}$ & & 2.81 & 1.01 \\
\hline$B 23$ & Jitter deteroent & 20757310 & 090 & $* * *$ & $\mathrm{~s}$ & & 2.81 & .67 & 852 & Little nackage & 24132740 - & 000 & $* * *$ & $\mathrm{~S}$ & & 3.02 & .73 \\
\hline D23 3 & Liter celergent & $20 / 5 / 31.0$ & .000 & & $\mathrm{~T}$ & & 2.63 & .90 & DO2 2 & Lilue package & $24132 / 4.0$ & .000 & & $T$ & & 2.89 & .87 \\
\hline B24 & Waste (nule) & 2078980.0 & 000 & $* * *$ & S & & 3.40 & .67 & $\mathrm{~B} 53$ & Using IFD & 15567560 & 000 & $* * *$ & S & & 2.30 & .81 \\
\hline D24 & viase (iuile) & & .000 & & $\mathrm{~T}$ & & 3.59 & .67 & Dw & لتسأ & (1530/0.0 & .000 & & $\mathrm{~T}$ & & 1.77 & .89 \\
\hline B25 & Recycle (newspaper) & 2310619.0 & .000 & $* * *$ & S & & 3.26 & .77 & B54 & Temperature control off & 1694261.0 & .000 & $* * *$ & S & & 3.02 & .79 \\
\hline & & & & & $\mathrm{T}$ & & 3.06 & 1.06 & & & & & & $\mathrm{~T}$ & & 3.48 & .75 \\
\hline B26 & Recycle & 1116555.5 & .000 & $* * *$ & $\mathrm{~S}$ & & 3.20 & .74 & B55 & Dishwahser & 137341.0 & .000 & $* * *$ & S & & 2.45 & .81 \\
\hline & (second-hand clothes) & & & & $\mathrm{T}$ & & 2.19 & .97 & BSS & Disnwanser & 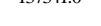 & .000 & & $\mathrm{~T}$ & & 2.91 & 1.00 \\
\hline B27 & My cup & 2204964.5 & .000 & $* * *$ & S & & 2.72 & .89 & $B 56$ & Eco-Cooking & 1834008.5 & .000 & $* * *$ & $\mathrm{~S}$ & & 2.98 & .69 \\
\hline $\mathrm{D} 27$ & & & .000 & & $\mathrm{~T}$ & & 2.55 & 1.14 & & & & & & $\mathrm{~T}$ & & 3.25 & .84 \\
\hline B28 & Proper cooking & 1732051.0 & 000 & $* * *$ & $\mathrm{~S}$ & & 2.93 & .67 & B57 & Jnsulation & 20649930 & 000 & **** & S & & 2.93 & .72 \\
\hline & & & & & $\mathrm{T}$ & & 3.27 & .77 & DO & IIIStidaturi & 2204993.0 & .000 & $x^{2}$ & $\mathrm{~T}$ & & 3.06 & .87 \\
\hline
\end{tabular}

${ }^{\mathrm{a}:}{ }^{* * *}: p<0.01 ;{ }^{* *}: p<0.05$ one-tail; ${ }^{\mathrm{b}}$ : S: Seoul, T: Tokyo; ${ }^{\mathrm{c}}$ : Standard deviation.

Figure 1. Comparison of practice rates between two cities.

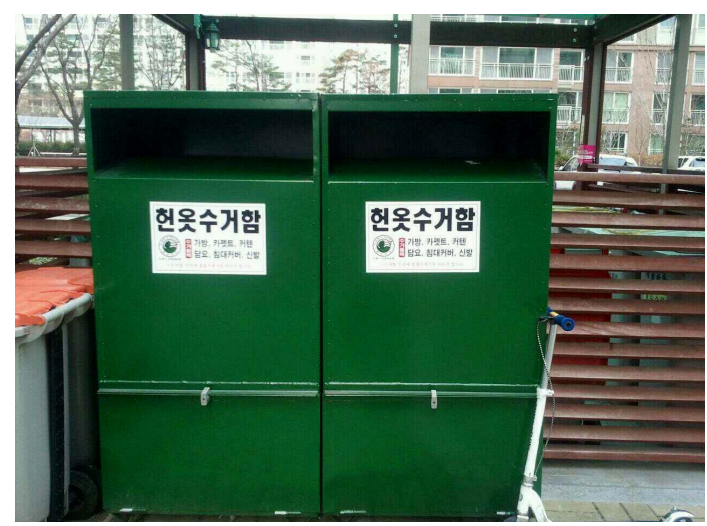

Figure 2. Old cloth collection boxes in Korea.

in landfills used for other combustible waste nationwide. Based on this policy, Korean people have had to separate their food waste from other waste and dispose of it in charged waste bags. This condition creates motivation for people to separate and reduce their food waste. On the other hand, the Tokyo metropolitan government collects and treats food waste along with other combustible waste. Hence, Seoul residents have the habit of separating their food waste and some residents try to reduce the food waste themselves through composting.

The policy effect on the behavior practice rate of "B51: My own bag” seems to be large. The Korean government has charged for plastic shopping bags nationwide since 1999, while free plastic shopping bags are distributed in most regions in Tokyo. This is reflected in the significantly ( $p<0.001)$ higher practice rate of B51 in Seoul (3.13) than in Tokyo (2.81). The effects of charging for shopping bags have also been discussed in previous studies. Ueta and Koizumi [24] compared the packing waste systems of Freiburg in Germany and Neyagawa in 
Japan and found that the charging system in Freiburg contributed to behaviors that reduce the use of disposable plastic shopping bags. Kurisu and Bortoleto [25] compared three mega prefectures (Aichi, Osaka, Tokyo) in Japan and found that the city that implemented a charging system for shopping bags showed significantly higher practice rates of people using their own bags. Hence, the policy of implementing a charging system can have a significant effect on the PEB practice rate.

\subsubsection{Influence of Personal Judgment}

As discussed above, some external conditions can affect PEB practice rates. However, personal reasons can also influence people's behaviors. To understand the characteristics of PEBs based on personal reasons, we used multiple correspondence analysis (MCA). MCA is one of the statistical techniques used to reveal the optimal quantification that describes the relationships between the categorical scores of each variable as well as the relationships between the variables themselves. The reasons selected from the list shown in Table 2 for practicing or not practicing behaviors were used as the column variables, while 50 PEBs were set as the row variables to give the input matrices for MCA.

The resulting scores were plotted as shown in Figures 3-6. Reasons and behaviors that are placed closer together are more closely connected.

Figures $\mathbf{3}$ and $\mathbf{4}$ show the reasons for practicing PEBs in Seoul and Tokyo respectively. Many PEBs were plotted close to the reason "Saving" in both Seoul and Tokyo. Monetary saving is considered one of the important fac- tors for PEBs [3,26]. Abrahams et al. [26] reviewed various previous studies related to monetary intervention for household energy conservation and also showed its effectiveness. "Saving" is the main reason for practicing most PEBs in the two target cities. If we look at the positions of the 11 reasons, the related reasons of "Habit" and "Convenience" are found close to "Saving." The positions reveal that the respondents in Tokyo perceive "Convenience" and "Habit" as closely connected to "Saving," and that these three reasons are their main reasons for practicing most PEBs, while the respondents in Seoul consider these reasons distinct from "Saving." The reasons that are particularly distinct are "Rule" and "Healthy." "Rule" is closely related to external forces like laws and regulations and so is different from other reasons for practicing PEBs. The behaviors close to the reason "Rule” are "B24: Waste (rule)" and "B25: Recycle (newspaper)" in both cities. These are behaviors practiced following the waste disposal rules set by the local governments. "B30: Food waste (dehydration)" is also close to "Rule" in Seoul, because food waste disposal is regulated by the law in Korea, as mentioned in 3.2.1. On the other hand, B30 is more closely related to "Moral" rather than "Rule" in Tokyo, where no regulations about food waste disposal exist. The PEBs closely related to "Healthy" are "B5: Using stairs," "B39: Bicycle or walking," and "B47: Organic goods,” all of which are related to health enhancement. In the case of "B6: Filter cleaning," Seoul respondents recognize the health advantage of this behavior, while Tokyo respondents practice this behavior as a "Habit."

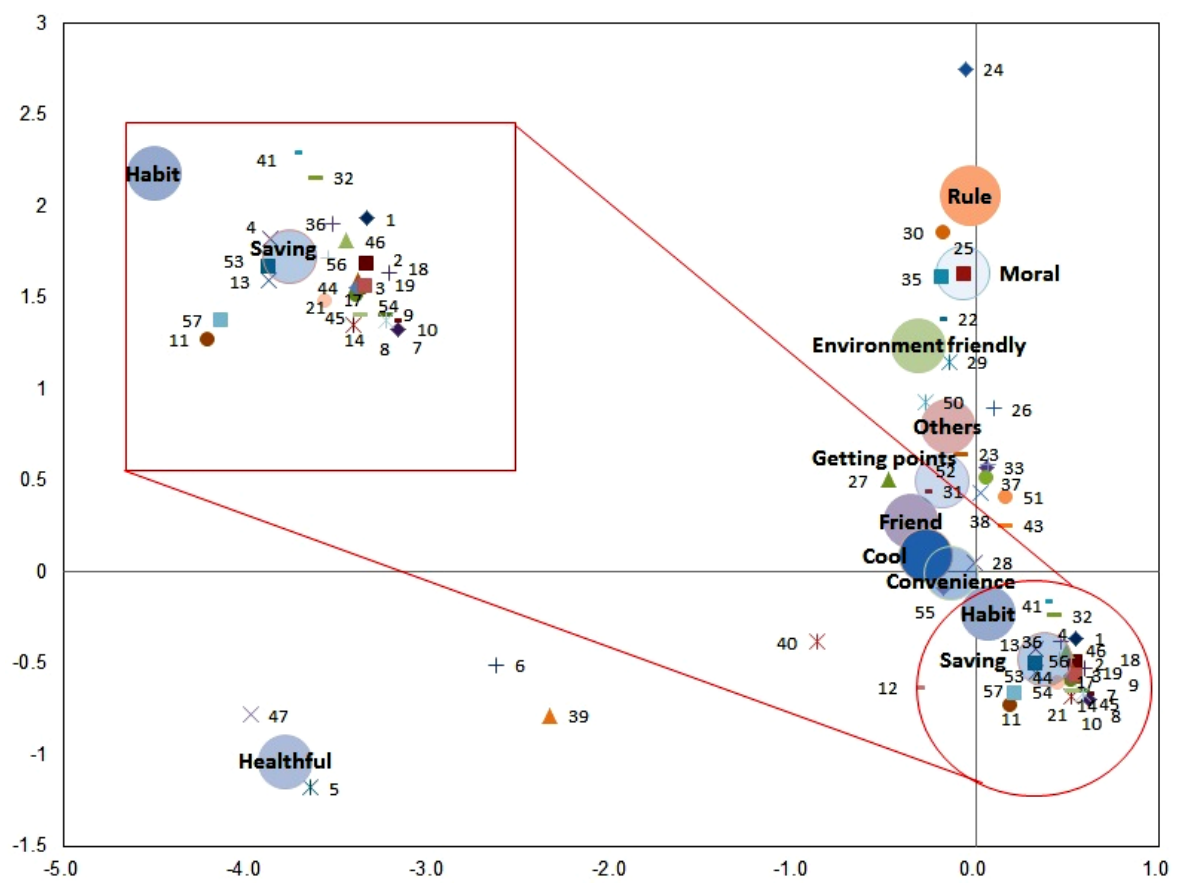

Figure 3. The matrix of practice group in Seoul (Cronbach's alpha $=\mathbf{0 . 6 5})$. 


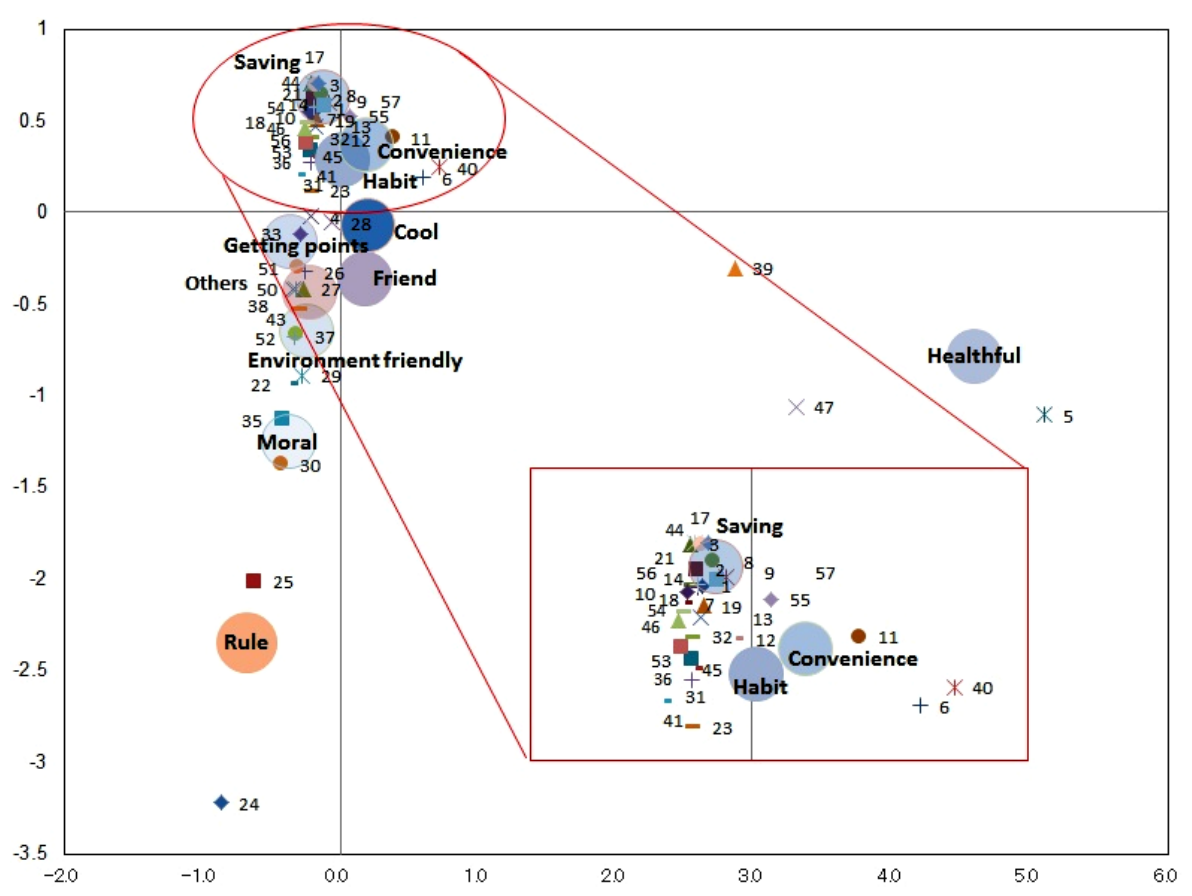

Figure 4. The matrix of practice group in Tokyo (Cronbach's alpha $=0.67$ ).

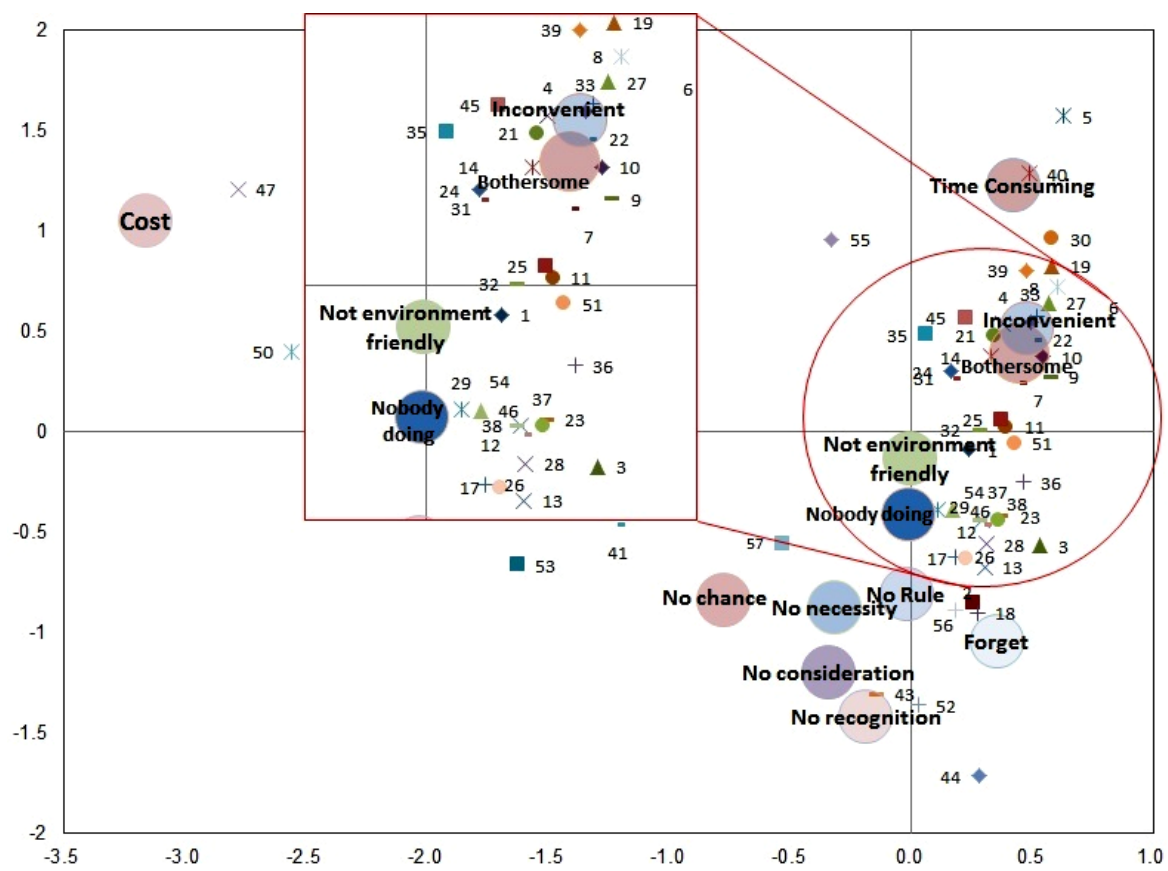

Figure 5. The matrix of non-practice group in Seoul (Cronbach's alpha $=\mathbf{0 . 5 8}$ ).

"Environment friendly" is relatively close to "Moral" in Seoul, while this reason is closely connected to "Following others" and "Recommendation" in Tokyo. Social norms, such as descriptive and subjective norms (i.e., the influence of others), are one of the most important factors in PEBs [7,8,10,27-29]. Ando et al. [7,8] have pointed out that the Japanese are more influenced by others, namely by subjective norms, when practicing PEBs than

\section{people in other countries.}

Figures 5 and $\mathbf{6}$ show the reasons for not practicing PEBs in Seoul and Tokyo respectively. The reason that appears most distinct from the others is "Cost." The behaviors that involve purchasing Eco-products, such as "B47: Organic goods," "B50: Eco-car," "B41: Eco-appliance," and "B53: LED," are closely related to this reason in both cities. Eco-products are generally more 


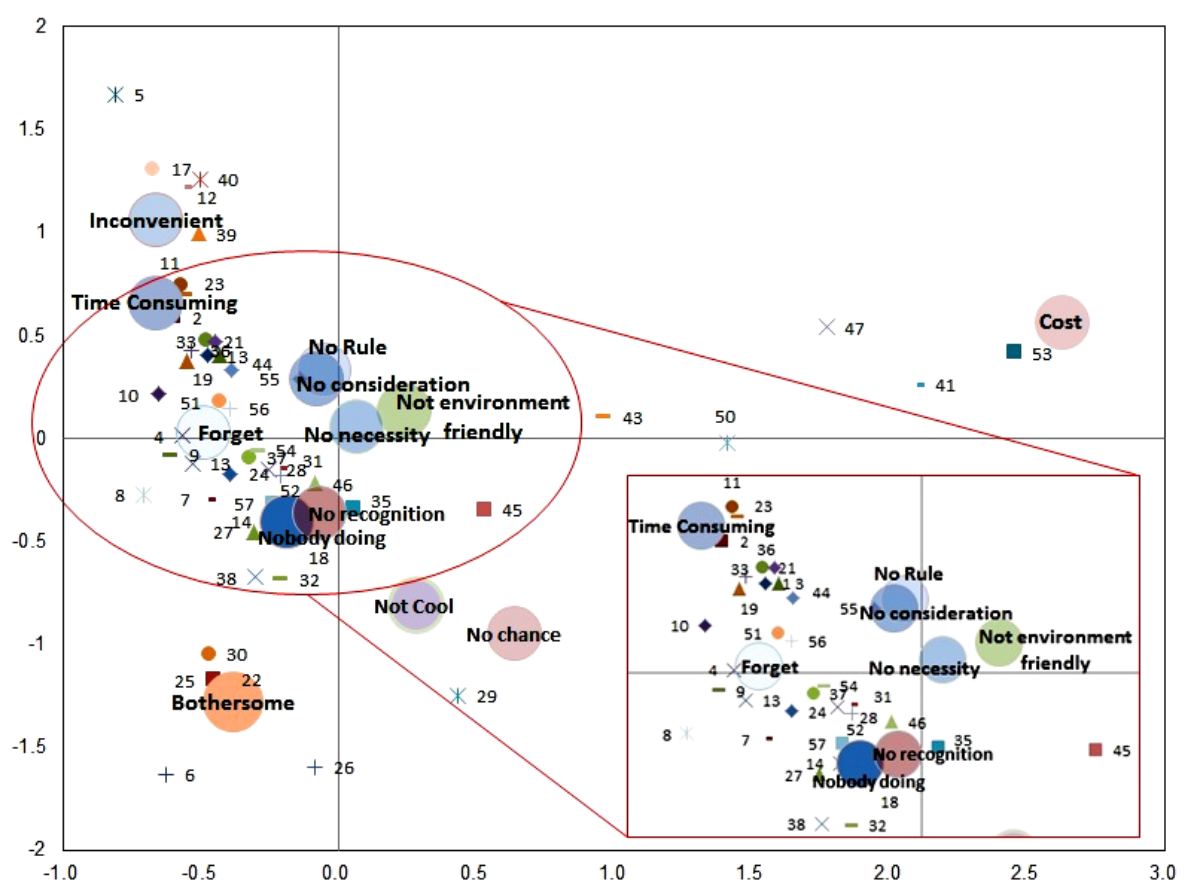

Figure 6. The matrix of non-practice group in Tokyo (Cronbach's alpha $=\mathbf{0 . 6 3})$.

expensive than regular products, and so "Cost" can be the main barrier to practicing these behaviors.

In Tokyo, the PEBs closely related to "Bothersome" are "B6: Filter cleaning," "B26: Recycle (second-hand clothes)," "B22: Used cooking oil," "B25: Recycle (newspaper)," and "B30: Food waste (dehydration)," while the PEBs close to "Inconvenience" are "B5: Elevator," "B17: Water saving (shower)," "B40: Public transportation," "B12: Ideal temperature (shower)," and "B39: Bicycle or walking”. The former PEBs require additional work, while the latter PEBs cause some discomfort as the result of practicing the behaviors. There is a very well-recognized distinction between "Bothersome" and "Inconvenience” in Tokyo, while these are perceived as similar concepts in Seoul.

Unlike Figures 3 and $\mathbf{4}$, the PEBs are not clustered close to any particular reason, but clusters do form near multiple reasons. This indicates that the internal barriers for PEBs are more diverse than the incentives. Multiple barriers can affect PEBs. This creates difficulties in removing the barriers for the PEBs.

\subsection{Effects of Demographics}

One of the factors that cause practice rate difference is socio-demographics. Gender and age are potentially important factors in determining PEBs practice rates. To understand the effect of gender and age, non-parametric statistical tests such as the Mann-Whitney test and Kruskal-Wallis (KW) test were applied. We selected these non-parametric tests because the original data did not show the normal distribution. However, the parametric test corresponding to the $\mathrm{KW}$ test, namely one-way ANOVA (analysis of variance), which is considered to give robust results even without the normal distribution requirement, was also applied.

A post hoc (multiple comparison) test was also conducted to discover which attributes differ in practice rate. Tukey-Kramer Hochberg's GT2 was selected for the behaviors showing homogeneity of variance, while Dunnett's T3 method was adapted for the others.

Tables 3 and 4 show the result of the effects of gender and age on the practice rates in the two cities. In terms of gender, 36 and 50 PEBs show significantly different practice rates between men and women in Seoul and Tokyo respectively. The practice rate of females is statistically higher than that of males in 33 out of 36 PEBs in Seoul and 37 out of 50 PEBs in Tokyo. The higher practice rates of PEBs in women have been reported in many previous studies [5,30,31]. It is easily understood that higher practice rates for the female respondents were observed in many homemaking PEBs, such as "B14: Ironing," "B21: Laundry," "B22: Used cooking oil,” "B23: Little detergent,” "B24: Waste (rule),” and "B25: Recycle (newspaper).”

In terms of age, 41 PEBs in Seoul and 32 PEBs in Tokyo show significantly different practice rates. The trend is similar in the two cities. Elder respondents tend to practice PEBs more than younger people. The same trend was also observed in waste prevention behaviors [25,30]. As Whitmarsh [32] pointed out, age can be a significant variable for several PEBs. The elder respon- 
Table 3. The effects of gender and age in Seoul.

\begin{tabular}{|c|c|c|c|c|c|c|c|c|c|c|c|}
\hline \multirow{3}{*}{$\begin{array}{l}\text { Behavior } \\
\text { Number }\end{array}$} & \multicolumn{5}{|c|}{ Gender } & \multicolumn{6}{|c|}{ Age } \\
\hline & \multicolumn{2}{|c|}{ Mann-Whitney } & \multicolumn{2}{|c|}{ Average } & \multirow{2}{*}{$\begin{array}{c}\text { High } \\
\text { practice }\end{array}$} & \multirow{2}{*}{$\begin{array}{c}\mathrm{HV}^{\mathrm{b}} \\
p\end{array}$} & \multirow{2}{*}{$\begin{array}{c}\text { One-Way ANOVAc } \\
p\end{array}$} & \multicolumn{2}{|c|}{ Kruskal Wallis } & \multicolumn{2}{|r|}{ Multiple-Comparison } \\
\hline & $\mathrm{U}$ & $p^{\mathrm{a}}$ & Male & Female & & & & $\chi^{2}$ & $p$ & $M^{d}$ & Interpretation $^{\mathrm{e}}$ \\
\hline B1 & 626682 & 0.000 & 2.4 & 2.5 & $\mathrm{~F}$ & 0.014 & 0.174 & 4.66 & 0.198 & & \\
\hline B2 & 694330 & 0.221 & 2.58 & 2.59 & & 0.000 & 0.000 & 43.23 & 0.000 & Т3 & $20 s, 30 s<40 s<50 s$ \\
\hline B3 & 680880 & 0.317 & 2.35 & 2.37 & & 0.003 & 0.002 & 15.52 & 0.001 & T3 & $30 \mathrm{~s}<50 \mathrm{~s}$ \\
\hline B4 & 613182 & 0.000 & 3.05 & 3.22 & $\mathrm{~F}$ & 0.000 & 0.000 & 37.7 & 0.000 & T3 & $20 \mathrm{~s}<30 \mathrm{~s}<40 \mathrm{~s}, 50 \mathrm{~s}$ \\
\hline B5 & 667387 & 0.080 & 2.09 & 2.04 & & 0.018 & 0.000 & 30.65 & 0.000 & T3 & $30 s, 20 s<50 s, 40 s$ \\
\hline B6 & 636998 & 0.003 & 2.4 & 2.49 & $\mathrm{~F}$ & 0.180 & 0.000 & 98.59 & 0.000 & GT2 & $20 \mathrm{~s}<30 \mathrm{~s}<40 \mathrm{~s}, 50 \mathrm{~s}$ \\
\hline B7 & 642046 & 0.000 & 3.29 & 3.41 & $\mathrm{~F}$ & 0.428 & 0.001 & 12.48 & 0.006 & GT2 & $30 \mathrm{~s}<40 \mathrm{~s}, 50 \mathrm{~s}$ \\
\hline B9 & 707392 & 0.371 & 3.09 & 3.11 & & 0.149 & 0.019 & 12.6 & 0.006 & GT2 & $50 \mathrm{~s}<20 \mathrm{~s}$ \\
\hline B10 & 664337 & 0.004 & 3.14 & 3.22 & $\mathrm{~F}$ & 0.000 & 0.005 & 8.65 & 0.034 & T3 & $20 \mathrm{~s}<40 \mathrm{~s}, 50 \mathrm{~s}$ \\
\hline B11 & 618941 & 0.000 & 2.78 & 2.91 & $\mathrm{~F}$ & 0.000 & 0.000 & 30.84 & 0.000 & T3 & $20 \mathrm{~s}<50 \mathrm{~s}, 40 \mathrm{~s}, 30 \mathrm{~s}<40 \mathrm{~s}$ \\
\hline B12 & 697620 & 0.115 & 2.95 & 2.92 & & 0.000 & 0.000 & 67.74 & 0.000 & T3 & $20 \mathrm{~s}<30 \mathrm{~s}<40 \mathrm{~s}, 50 \mathrm{~s}$ \\
\hline B13 & 196145 & 0.025 & 2.7 & 2.77 & $\mathrm{~F}$ & 0.017 & 0.143 & 5.16 & 0.160 & & \\
\hline B14 & 519981 & 0.000 & 2.76 & 3.02 & $\mathrm{~F}$ & 0.000 & 0.000 & 18.73 & 0.000 & T3 & $20 \mathrm{~s}<40 \mathrm{~s}, 50 \mathrm{~s}$ \\
\hline B17 & 674917 & 0.008 & 2.67 & 2.75 & $\mathrm{~F}$ & 0.000 & 0.000 & 38.11 & 0.000 & T3 & $20 \mathrm{~s}<30 \mathrm{~s}<40 \mathrm{~s}, 50 \mathrm{~s}$ \\
\hline B18 & 680598 & 0.442 & 2.12 & 2.14 & & 0.582 & 0.000 & 45.65 & 0.000 & GT2 & 20 s, $30 \mathrm{~s}<40 \mathrm{~s}, 50 \mathrm{~s}$ \\
\hline B19 & 637978 & 0.016 & 2.13 & 2.06 & M & 0.042 & 0.000 & 24.79 & 0.000 & T3 & $30 \mathrm{~s}<40 \mathrm{~s}, 30 \mathrm{~s}, 20 \mathrm{~s}<50 \mathrm{~s}$ \\
\hline B23 & 642219 & 0.009 & 2.77 & 2.84 & $\mathrm{~F}$ & 0.000 & 0.000 & 53.7 & 0.000 & T3 & $20 \mathrm{~s}<40 \mathrm{~s}, 20 \mathrm{~s}, 30 \mathrm{~s}, 40 \mathrm{~s}<50 \mathrm{~s}$ \\
\hline B24 & 629187 & 0.000 & 3.34 & 3.47 & $\mathrm{~F}$ & 0.000 & 0.001 & 11.47 & 0.009 & T3 & $20 \mathrm{~s}<40 \mathrm{~s}, 50 \mathrm{~s}$ \\
\hline B25 & 650122 & 0.001 & 3.21 & 3.31 & $\mathrm{~F}$ & 0.006 & 0.498 & 1.14 & 0.767 & & \\
\hline B26 & 563394 & 0.000 & 3.07 & 3.32 & $\mathrm{~F}$ & 0.179 & 0.000 & 26.73 & 0.000 & GT2 & $20 \mathrm{~s}<40 \mathrm{~s}, 50 \mathrm{~s}, 30 \mathrm{~s}<50 \mathrm{~s}$ \\
\hline B27 & 613052 & 0.000 & 2.62 & 2.81 & $\mathrm{~F}$ & 0.000 & 0.000 & 25.84 & 0.000 & T3 & $20 s, 30 s, 40 s<50 s$ \\
\hline B28 & 646405 & 0.002 & 2.89 & 2.97 & $\mathrm{~F}$ & 0.000 & 0.003 & 13.75 & 0.003 & T3 & 20 s, 30 s $<50 s$ \\
\hline B29 & 633303 & 0.144 & 1.91 & 1.87 & & 0.007 & 0.000 & 19.64 & 0.000 & T3 & $30 \mathrm{~s}<20 \mathrm{~s}, 50 \mathrm{~s}$ \\
\hline B30 & 622256 & 0.002 & 2.67 & 2.77 & $\mathrm{~F}$ & 0.000 & 0.000 & 32.57 & 0.000 & T3 & 20 s, 30 s $<40 s<50 s$ \\
\hline B31 & 667711 & 0.073 & 3 & 3.05 & & 0.000 & 0.086 & 7.43 & 0.059 & & \\
\hline B32 & 648318 & 0.000 & 3.02 & 3.13 & $\mathrm{~F}$ & 0.001 & 0.016 & 10.42 & 0.015 & T3 & $30 \mathrm{~s}<40 \mathrm{~s}$ \\
\hline B33 & 643500 & 0.000 & 2.83 & 2.97 & $\mathrm{~F}$ & 0.000 & 0.000 & 43.19 & 0.000 & T3 & $30 \mathrm{~s}, 20 \mathrm{~s}<40 \mathrm{~s}, 50 \mathrm{~s}$ \\
\hline B35 & 369833 & 0.004 & 2.93 & 3.02 & $\mathrm{~F}$ & 0.000 & 0.000 & 17.09 & 0.001 & T3 & $20 \mathrm{~s}<30 \mathrm{~s}, 40 \mathrm{~s}, 50 \mathrm{~s}$ \\
\hline B36 & 670495 & 0.001 & 2.84 & 2.94 & $\mathrm{~F}$ & 0.000 & 0.007 & 11.73 & 0.008 & T3 & $20 \mathrm{~s}<50 \mathrm{~s}$ \\
\hline B37 & 384090 & 0.165 & 3.05 & 3.08 & & 0.029 & 0.000 & 18.35 & 0.000 & T3 & $20 \mathrm{~s}, 30 \mathrm{~s}, 40 \mathrm{~s}<50 \mathrm{~s}$ \\
\hline B38 & 380448 & 0.128 & 3 & 3.03 & & 0.010 & 0.000 & 16.72 & 0.001 & T3 & $20 \mathrm{~s}<40$ s, 50s \\
\hline B39 & 365973 & 0.003 & 3.03 & 3.12 & $\mathrm{~F}$ & 0.071 & 0.135 & 7.16 & 0.067 & & \\
\hline B40 & 606689 & 0.000 & 3.11 & 3.32 & $\mathrm{~F}$ & 0.256 & 0.000 & 55.14 & 0.000 & GT2 & $40 s, 30 s, 50 s<20 s$ \\
\hline B41 & 634290 & 0.000 & 2.91 & 3.02 & $\mathrm{~F}$ & 0.000 & 0.006 & 11.6 & 0.009 & T3 & $20 \mathrm{~s}<50 \mathrm{~s}$ \\
\hline
\end{tabular}


Continued

\begin{tabular}{|c|c|c|c|c|c|c|c|c|c|c|c|}
\hline B43 & 698791 & 0.361 & 2.49 & 2.48 & & 0.073 & 0.005 & 13.46 & 0.004 & GT2 & $30 s<50 s, 40 s$ \\
\hline B44 & 668094 & 0.039 & 2.92 & 2.96 & M & 0.000 & 0.000 & 21.89 & 0.000 & $\mathrm{~T} 3$ & $20 s, 30 s<40 s, 50 s$ \\
\hline B45 & 688834 & 0.140 & 3.06 & 3.09 & & 0.053 & 0.114 & 6.04 & 0.109 & & \\
\hline B46 & 614145 & 0.000 & 2.88 & 3.05 & $\mathrm{~F}$ & 0.000 & 0.001 & 14.59 & 0.002 & $\mathrm{~T} 3$ & $20 \mathrm{~s}<40 \mathrm{~s}, 50 \mathrm{~s}$ \\
\hline B47 & 674906 & 0.160 & 2.5 & 2.53 & & 0.002 & 0.000 & 30.31 & 0.000 & $\mathrm{~T} 3$ & $20 s, 30 s, 40 s<50 s$ \\
\hline B50 & 618445 & 0.094 & 2.31 & 2.35 & & 0.041 & 0.000 & 27.75 & 0.000 & T3 & $30 s<40 s, 50 s$ \\
\hline B51 & 584053 & 0.000 & 3.01 & 3.24 & $\mathrm{~F}$ & 0.185 & 0.000 & 51.29 & 0.000 & GT2 & 20 s, 30s $<40 s, 50 s$ \\
\hline B52 & 580953 & 0.000 & 2.9 & 3.13 & $\mathrm{~F}$ & 0.239 & 0.000 & 36.7 & 0.000 & GT2 & 20 s, $30 \mathrm{~s}<40 \mathrm{~s}, 50 \mathrm{~s}$ \\
\hline B53 & 607447 & 0.000 & 2.22 & 2.38 & $\mathrm{~F}$ & 0.001 & 0.010 & 12.45 & 0.006 & T3 & \\
\hline B54 & 648370 & 0.005 & 2.99 & 3.06 & $\mathrm{~F}$ & 0.002 & 0.080 & 4.46 & 0.216 & & \\
\hline B55 & 65191 & 0.022 & 2.5 & 2.38 & $\mathrm{M}$ & 0.258 & 0.378 & 2.08 & 0.556 & & \\
\hline B56 & 607045 & 0.000 & 2.91 & 3.05 & $\mathrm{~F}$ & 0.000 & 0.000 & 18.74 & 0.000 & $\mathrm{~T} 3$ & $20 \mathrm{~s}<40 \mathrm{~s}, 50 \mathrm{~s}, 30 \mathrm{~s}<50 \mathrm{~s}$ \\
\hline B57 & 628005 & 0.000 & 2.87 & 2.99 & $\mathrm{~F}$ & 0.000 & 0.000 & 19.23 & 0.000 & Т3 & $20 s<40 s, 50 s, 30 s<50 s$ \\
\hline
\end{tabular}

Note: Significant $p$ value was indicated in bold. ${ }^{\mathrm{a}}$ One-tail; ${ }^{\mathrm{b}} \mathrm{HV}$ : Homogeneity-of Variance; ${ }^{\mathrm{c}}$ Be reference; ${ }^{\mathrm{d}}$ Post-Hoc method, GT2: Tukey-Kramer Hochberg's GT2, T3 : Dunnett's T3; ${ }^{\mathrm{e}} \mathrm{m}<\mathrm{k}$ : $\mathrm{m}$ is significantly better than $\mathrm{k}(p<0.01) \mathrm{m}, \mathrm{j}<\mathrm{k}$ : There is no significantly difference between $\mathrm{m}$ and $\mathrm{j}$, but $\mathrm{m}$ and $\mathrm{j}$ are significantly better than $\mathrm{k}(p<0.01)$.

Table 4. The effects of gender and age in Tokyo.

\begin{tabular}{|c|c|c|c|c|c|c|c|c|c|c|c|}
\hline \multirow{3}{*}{$\begin{array}{l}\text { Behavior } \\
\text { Number }\end{array}$} & \multicolumn{5}{|c|}{ Gender } & \multicolumn{6}{|c|}{ Age } \\
\hline & \multicolumn{2}{|c|}{ Mann-Whitney } & \multicolumn{2}{|c|}{ Average } & \multirow{2}{*}{$\begin{array}{c}\text { High } \\
\text { practice }\end{array}$} & \multirow{2}{*}{$\begin{array}{c}\mathrm{HV}^{\mathrm{b}} \\
p\end{array}$} & \multirow{2}{*}{$\begin{array}{c}\text { One-Way ANOVA } \\
p\end{array}$} & \multicolumn{2}{|c|}{ Kruskal Wallis } & \multicolumn{2}{|r|}{ Multiple-Comparison } \\
\hline & $U$ & $p^{\mathrm{a}}$ & Male & Female & & & & $\chi^{2}$ & $p$ & $M^{d}$ & Interpretation $^{\mathrm{e}}$ \\
\hline B1 & 466511 & 0.000 & 2.7 & 2.9 & $\mathrm{~F}$ & 0.118 & 0.572 & 2.58 & 0.461 & & \\
\hline B2 & 575879 & 0.266 & 2.83 & 2.86 & & 0.000 & 0.323 & 2.51 & 0.473 & & \\
\hline B3 & 490450 & 0.005 & 2.42 & 2.53 & $\mathrm{~F}$ & 0.000 & 0.499 & 2.56 & 0.465 & & \\
\hline B4 & 439314 & 0.000 & 3.04 & 3.38 & $\mathrm{~F}$ & 0.187 & 0.000 & 15.3 & 0.002 & GT2 & $20 s<30 s, 40 s, 50 s$ \\
\hline B5 & 577393 & 0.111 & 2.17 & 2.12 & & 0.004 & 0.542 & 2.79 & 0.424 & & \\
\hline B6 & 510830 & 0.005 & 2.31 & 2.41 & $\mathrm{~F}$ & 0.094 & 0.000 & 58.36 & 0.000 & GT2 & $20 \mathrm{~s}<30 \mathrm{~s}, 50 \mathrm{~s}, 40 \mathrm{~s}$ \\
\hline B7 & 510265 & 0.000 & 3.29 & 3.52 & $\mathrm{~F}$ & 0.005 & 0.021 & 10.49 & 0.015 & Т3 & $20 \mathrm{~s}<40 \mathrm{~s}$ \\
\hline B9 & 568412 & 0.024 & 2.86 & 2.94 & $\mathrm{~F}$ & 0.024 & 0.010 & 13.66 & 0.003 & T3 & $50 s<30 s$ \\
\hline B10 & 529538 & 0.000 & 3.05 & 3.23 & $\mathrm{~F}$ & 0.985 & 0.195 & 5.08 & 0.166 & & \\
\hline B11 & 479817 & 0.000 & 3.04 & 3.34 & $\mathrm{~F}$ & 0.058 & 0.012 & 8.41 & 0.038 & GT2 & $20 \mathrm{~s}<40 \mathrm{~s}, 50 \mathrm{~s}$ \\
\hline B12 & 579839 & 0.207 & 2.18 & 2.22 & & 0.188 & 0.000 & 31.13 & 0.000 & GT2 & $20 \mathrm{~s}<40 \mathrm{~s}, 50 \mathrm{~s}, 30 \mathrm{~s}<50 \mathrm{~s}$ \\
\hline B13 & 188661 & 0.000 & 3.02 & 3.3 & $\mathrm{~F}$ & 0.008 & 0.011 & 7.71 & 0.052 & & \\
\hline B14 & 248215 & 0.000 & 2.82 & 3.25 & $\mathrm{~F}$ & 0.000 & 0.000 & 28.59 & 0.000 & Т3 & $20 s<30 s, 50 s, 40 s, 30 s<40 s$ \\
\hline B17 & 560229 & 0.008 & 2.62 & 2.71 & $\mathrm{~F}$ & 0.000 & 0.000 & 44.49 & 0.000 & T3 & 20 s, 30 s $<40$ s, 50s \\
\hline B18 & 477269 & 0.000 & 1.52 & 1.42 & M & 0.001 & 0.037 & 11.05 & 0.011 & Т3 & \\
\hline B19 & 481233 & 0.104 & 1.97 & 2.05 & & 0.528 & 0.000 & 22.19 & 0.000 & GT2 & $30 \mathrm{~s}<40 \mathrm{~s}, 50 \mathrm{~s}$ \\
\hline B22 & 324903 & 0.000 & 2.64 & 3.13 & $\mathrm{~F}$ & 0.000 & 0.000 & 36.24 & 0.000 & T3 & $20 s<30 s, 40 s, 50 s$ \\
\hline B23 & 449149 & 0.000 & 2.54 & 2.72 & $\mathrm{~F}$ & 0.000 & 0.000 & 33.03 & 0.000 & T3 & $20 s, 30 s<40 s, 50 s$ \\
\hline
\end{tabular}


Continued

\begin{tabular}{|c|c|c|c|c|c|c|c|c|c|c|c|}
\hline B24 & 495014 & 0.000 & 3.5 & 3.68 & $\mathrm{~F}$ & 0.000 & 0.000 & 58.39 & 0.000 & T3 & $20 \mathrm{~s}<30 \mathrm{~s},<50 \mathrm{~s}, 40 \mathrm{~s}$ \\
\hline B25 & 462205 & 0.000 & 2.93 & 3.19 & $\mathrm{~F}$ & 0.000 & 0.000 & 69.87 & 0.000 & T3 & $20 \mathrm{~s}<30$ s, $<40$ s, $50 \mathrm{~s}$ \\
\hline B26 & 451593 & 0.000 & 2.02 & 2.36 & $\mathrm{~F}$ & 0.100 & 0.465 & 3.88 & 0.275 & & \\
\hline B27 & 441045 & 0.000 & 2.41 & 2.7 & $\mathrm{~F}$ & 0.033 & 0.000 & 22.95 & 0.000 & Т3 & 20 s, $30 s<40 s$ \\
\hline B28 & 494261 & 0.078 & 3.23 & 3.31 & & 0.244 & 0.219 & 6.11 & 0.106 & & \\
\hline B29 & 442434 & 0.000 & 1.35 & 1.23 & M & 0.000 & 0.045 & 7.44 & 0.059 & & \\
\hline B30 & 384461 & 0.000 & 2.44 & 2.79 & $\mathrm{~F}$ & 0.000 & 0.000 & 52.77 & 0.000 & Т3 & $20 \mathrm{~s}<30 \mathrm{~s}, 40 \mathrm{~s}, 50 \mathrm{~s}, 30 \mathrm{~s}<50 \mathrm{~s}$ \\
\hline B31 & 465825 & 0.000 & 2.27 & 2.46 & $\mathrm{~F}$ & 0.005 & 0.264 & 4.2 & 0.241 & & \\
\hline B32 & 528518 & 0.000 & 2.77 & 2.96 & $\mathrm{~F}$ & 0.105 & 0.003 & 15.64 & 0.001 & GT2 & $30 s<40$ s, 20s \\
\hline B33 & 522140 & 0.000 & 2.49 & 2.7 & $\mathrm{~F}$ & 0.000 & 0.004 & 14.53 & 0.002 & T3 & $30 s<50 s$ \\
\hline B35 & 66855 & 0.467 & 2.53 & 2.53 & & 0.257 & 0.871 & 0.95 & 0.814 & & \\
\hline B36 & 564121 & 0.445 & 2.84 & 2.84 & & 0.082 & 0.174 & 4.42 & 0.220 & & \\
\hline B37 & 68624 & 0.364 & 3.16 & 3.2 & & 0.026 & 0.031 & 6.15 & 0.105 & & \\
\hline B38 & 62869 & 0.120 & 3 & 2.92 & & 0.063 & 0.041 & 8.55 & 0.036 & GT2 & $20 s<50 s$ \\
\hline B39 & 76414 & 0.001 & 3.3 & 3.43 & $\mathrm{~F}$ & 0.601 & 0.086 & 8.86 & 0.031 & GT2 & \\
\hline B40 & 568306 & 0.003 & 3.27 & 3.37 & $\mathrm{~F}$ & 0.006 & 0.000 & 33.19 & 0.000 & T3 & $30 s<40$ s, 30s, $50 s<20 s$ \\
\hline B41 & 494865 & 0.000 & 2.51 & 2.68 & $\mathrm{~F}$ & 0.000 & 0.000 & 18.77 & 0.000 & $\mathrm{~T} 3$ & $20 \mathrm{~s}<40 \mathrm{~s}, 50 \mathrm{~s}, 30 \mathrm{~s}<50 \mathrm{~s}$ \\
\hline B43 & 529373 & 0.000 & 2.15 & 2.27 & $\mathrm{~F}$ & 0.033 & 0.005 & 13.71 & 0.003 & GT2 & 20 s, $30 s<40 s$ \\
\hline B44 & 589998 & 0.163 & 2.93 & 2.91 & & 0.004 & 0.910 & 0.84 & 0.841 & & \\
\hline B45 & 588463 & 0.162 & 2.92 & 2.97 & & 0.025 & 0.056 & 6.04 & 0.110 & & \\
\hline B46 & 497921 & 0.000 & 3.15 & 3.37 & $\mathrm{~F}$ & 0.000 & 0.617 & 3.89 & 0.274 & & \\
\hline B47 & 500835 & 0.000 & 1.95 & 2.1 & $\mathrm{~F}$ & 0.298 & 0.000 & 33.48 & 0.000 & GT2 & $20 \mathrm{~s}<40 \mathrm{~s}, 50 \mathrm{~s}, 30 \mathrm{~s}<50 \mathrm{~s}$ \\
\hline B50 & 288283 & 0.089 & 2.29 & 2.37 & & 0.017 & 0.085 & 7.6 & 0.055 & & \\
\hline B51 & 428616 & 0.000 & 2.57 & 3.05 & $\mathrm{~F}$ & 0.018 & 0.000 & 32.87 & 0.000 & Т3 & $20 \mathrm{~s}<30 \mathrm{~s}, 50 \mathrm{~s}, 40 \mathrm{~s}, 30 \mathrm{~s}<40 \mathrm{~s}$ \\
\hline B52 & 483229 & 0.000 & 2.75 & 3.04 & $\mathrm{~F}$ & 0.000 & 0.000 & 34.77 & 0.000 & Т3 & $20 \mathrm{~s}<50 \mathrm{~s}, 40 \mathrm{~s}, 30 \mathrm{~s}<40 \mathrm{~s}$ \\
\hline B53 & 511397 & 0.023 & 1.73 & 1.8 & $\mathrm{~F}$ & 0.952 & 0.042 & 11 & 0.012 & GT2 & $20 \mathrm{~s}<50 \mathrm{~s}$ \\
\hline B54 & 486947 & 0.000 & 3.34 & 3.62 & $\mathrm{~F}$ & 0.000 & 0.137 & 2.91 & 0.406 & & \\
\hline B55 & 31423 & 0.296 & 2.89 & 2.93 & & 0.003 & 0.000 & 22.4 & 0.000 & T3 & $50 \mathrm{~s}<30 \mathrm{~s}, 40 \mathrm{~s}$ \\
\hline B56 & 375951 & 0.000 & 3.04 & 3.45 & $\mathrm{~F}$ & 0.001 & 0.002 & 11.65 & 0.009 & $\mathrm{~T} 3$ & $20 \mathrm{~s}<40 \mathrm{~s}, 30 \mathrm{~s}$ \\
\hline B57 & 501362 & 0.000 & 2.94 & 3.18 & $\mathrm{~F}$ & 0.000 & 0.003 & 9.72 & 0.021 & T3 & $20 \mathrm{~s}<30 \mathrm{~s}, 40 \mathrm{~s}$ \\
\hline
\end{tabular}

Note: Significant $p$ value was indicated in bold. ${ }^{\mathrm{a}}$ One-tail; ${ }^{\mathrm{b}} \mathrm{HV}$ : Homogeneity-of variance; 'Be reference; ${ }^{\mathrm{d}}$ Post-Hoc method, GT2: Tukey-Kramer Hochberg's GT2, T3: Dunnett's T3; ${ }^{\mathrm{e}} \mathrm{m}<\mathrm{k}$ : $\mathrm{m}$ is significantly better than $\mathrm{k}(p<0.01) \mathrm{m}, \mathrm{j}<\mathrm{k}$ : There is no significantly difference between $\mathrm{m}$ and $\mathrm{j}$, but $\mathrm{m}$ and $\mathrm{j}$ are significantly better than $\mathrm{k}(p<0.01)$.

dents show higher practice rates in saving energy related to the use of lights, whereas the younger people show relatively higher scores for mobility. Our results also show that younger respondents have higher practice rates for "B40: Public transportation" than elder people in both cities.

The previous cross-country studies like Hunter et al. [33] and Aoyagi-Usui et al. [5] imply that the influences of gender and age on behaviors can be different in different countries, but insignificant differences in socio- demographics were observed between Seoul and Tokyo in our study. Comparison within the Asian region appears to yield quite similar trends in basic variables like socio-demographics for the PEBs.

\section{Conclusion}

We selected various PEBs and discussed the practice rates and influential factors using Seoul and Tokyo as the case study areas. Some external forces like policy and 
infrastructure influence the practice rate differences in some PEBs. Relationships between the PEBs and internal incentives and barriers are visualized using MCA. The positions of the reasons to practice or not to practice the PEBs provide us with implications about the common and different perceptions of reasons for practicing/not practicing PEBs in the two cities. Monetary saving is considered to be the most common influential factor for many PEBs. Health is a different type of incentive from other factors and can be an effective factor for some PEBs relating to health improvement. The reasons for some PEBs are quite different for the two cities, indicating that different reasons can increase or suppress these PEBs. Unlike the results of the MCA, the sociodemographic effects on the practice rates show little difference between the two cities. Our study can contribute to the holistic understanding of various PEBs and can be used to consider effective measures to enhance people's PEBs by promoting incentives or removing the barriers for each PEB.

\section{REFERENCES}

[1] Ministry of Environment, Republic of Korea, “The National Consciousness Census for Environmental Conservation," 2008.

http://webbook.me.go.kr/DLi-File/pdf/2009/11/183579.pdf

[2] P. W. Schultz, "Knowledge, Information, and Household Recycling: Examining the Knowledge-Deficit Model of Behavior Change," In: T. Dietz and P. C. Stern, Eds., New Tools for Environmental Protection: Education, Information, and Voluntary Measures, The National Academic Press, 2002, pp. 67-82.

[3] A. Kollmuss and J. Agyman, "Mind the Gap: Why Do People Act Environmentally and What Are the Barriers to Pro-Environmental Behavior?” Environmental Education Research, Vol. 8, No. 3, 2002, pp. 239-259. doi:10.1080/13504620220145401

[4] D. Abrams, K. Ando and S. Hinkle, "Psychological Attachment to the Group: Cross-Cultural Differences in Organizational Identification and Subjective Norms as Predictors of Workers' Turnover Intentions," Personality and Social Psychology Bulletin, Vol. 24, No. 10, 1998, pp. 1027-1039. doi:10.1177/01461672982410001

[5] M. Aoyagi-Usui, H. Vinken and A. Kuribayashi, "ProEnvironmental Attitude and Behaviors: An International Comparison,” Human Ecology Review, Vol. 10, No. 1, 2003, pp. 23-31.

[6] J. I. M. De Groot and L. Steg, "Value Orientations and Environmental Beliefs in Five Countries: Validity of an Instrument to Measure Egoistic, Altruistic and Biospheric Value Orientations," Journal of Cross-Cultural Psychology, Vol. 38, No. 3, 2007, pp. 318-332. doi:10.1177/0022022107300278

[7] K. Ando, S. Ohnuma and E. C. Chang, "Comparing Normative Influences as Determinants of Environmentally Conscious Behaviours between the USA and Japan,”
Asian Journal Of Social Psychology, Vol. 10, No. 3, 2007, pp. 171-178. doi:10.1111/j.1467-839X.2007.00223.x

[8] K. Ando, S. Ohnuma, B. Anke, E. Matthies and J. Sugiura, "Determinants of Individual and Collective Pro-Environmental Behaviors: Comparing Germany and Japan,” Journal of Environmental Information Science, Vol. 38, No. 5, 2010, pp. 21-32.

[9] M. Cordano, S. Welcomer, R. F. Scherer, L. Pradenas and V. Parada, "A Cross-Cultural Assessment of Three Theories of Pro-Environmental Behavior: A Comparison between Business Students of Chile and the United States," Environment and Behavior, Vol. 43, No. 5, 2011, pp. 634-657. doi:10.1177/0013916510378528

[10] R. B. Cialdini, R. R. Reno and C. A. Kallgren, “A Focus Theory of Normative Conduct: Recycling the Concept of Norms to Reduce Littering in Public Places,” Journal of Personality and Social Psychology, Vol. 58, No. 6, 1990, pp. 1015-1026. doi:10.1037/0022-3514.58.6.1015

[11] J. Hornik, J. Cherian, M. Madansky and C. Narayana, "Determinants of Recycling Behavior: A Synthesis of Research Results,” Journal of Socio-Economics, Vol. 24, No. 1, 1995, pp. 105-127. doi:10.1016/1053-5357(95)90032-2

[12] J. J. Lindsay and A. Strathman, "Predictors of Recycling Behavior: An Application of a Modified Health Belief Model," Journal of Applied Social Psychology, Vol. 27, No. 20, 1997, pp. 1799-1823. doi:10.1111/j.1559-1816.1997.tb01626.x

[13] P. W. Schultz, "Changing Behavior with Normative Feedback Interventions: A Field Experiment on Curbside Recycling," Basic and Applied Social Psychology, Vol. 21, No. 1, 1998, pp. 25-36.

[14] E. S. Iyer and R. K. Kashyap, “Consumer Recycling: Role of Incentives, Information, and Social Class," Journal of Consumer Behaviour, Vol. 6, No. 1, 2007, pp. 3247. doi:10.1002/cb.206

[15] R. A. Winett, J. W. Hatcher, T. R. Fort, I. N. Leckliter, S. Q. Love, A. W. Riley and J. F. Fishback, "The Effects of Videotape Modeling and Daily Feedback on Residential Electricity Conservation, Home Temperature and Humidity, Perceived Comfort, and Clothing Worn: Winter and Summer," Journal of Applied Behavior Analysis, Vol. 15, No. 3, 1982, pp. 381-402. doi:10.1901/jaba.1982.15-381

[16] J. S. Black, P. C. Stern and J. T. Elworth, "Personal and Contextual Influences on Household Energy Adaptations," Journal of Applied Psychology, Vol. 70, No. 1, 1985, pp. 3-21. doi:10.1037/0021-9010.70.1.3

[17] P. C. Stern, "What Psychology Knows about Energy Conservation,” American Psychologist, Vol. 47, No. 10, 1992, pp. 1224-1234. doi:10.1037/0003-066X.47.10.1224

[18] C. F. Clark, M. J. Kotchen and M. Moore, "Internal and External Influences on Pro-Environmental Behavior: Participation in a Green Electricity Program,” Journal of Environmental Psychology, Vol. 23, 2003, pp. 237-246. doi:10.1016/S0272-4944(02)00105-6

[19] W. Poortinga, L. Steg and C. Vlek, "Values, Environmental Concern, and Environmental Behavior: A Study into Household Energy Use,” Environment \& Behavior, Vol. 36, No. 1, 2004, pp. 70-93. doi:10.1177/0013916503251466 
[20] S. C. Thompson and K. Stoutemyer, "Water Use as a Commons Dilemma: The Effects of Education That Focuses on Long-Term Consequences and Individual Action," Environment and Behavior, Vol. 23, No. 3, 1991, pp. 314-333. doi:10.1177/0013916591233004

[21] A. Hurlimann, S. Dolnicar and P. Meyer, "Understanding Behaviour to Inform Water Supply Management in Developed Nations-A Review of Literature, Conceptual Model and Research Agenda,” Journal of Environmental Management, Vol. 91, No. 1, 2009, pp. 47-56. doi:10.1016/j.jenvman.2009.07.014

[22] R. M. Willis, R. A. Stewart, K. Panuwatwanich, P. R. Williams and A. L. Hollingsworth, "Quantifying the Influence of Environmental and Water Conservation Attitudes on Household End Use Water Consumption," Journal of Environmental Management, Vol. 92, No. 8, 2011, pp. 1996-2009. doi:10.1016/j.jenvman.2011.03.023

[23] E. Aoki, K. H. Kurisu, J. Nakatani and K. Hanaki, “Current State and Interregional Comparison of Citizen's Environmental Behavior by 47 Prefectures,” Japan Journal of JSCE, Vol. 38, 2010, pp. 17-26.

[24] K. Ueta and H. Koizumi, "Reducing Household Waste: Japan Learns from Germany,” Environment: Science and Policy for Sustainable Development, Vol. 43, No. 9, 2001, pp. 20-32. doi:10.1080/00139150109604512

[25] K. H. Kurisu and A. P. Bortoleto, "Comparison of Waste Prevention Behaviors among Three Japanese Megacity Regions in the Context of Local Measures and SocioDemographics,” Waste Management, Vol. 31, No. 7, 2011, pp. 1441-1449. doi:10.1016/j.wasman.2011.03.008

[26] W. Abrahamse, L. Steg, C. Vlek and T. Rothengatter, “A Review of Intervention Studies Aimed at Household En- ergy Conservation," Journal of Environmental Psychology, Vol. 25, No. 3, 2005, pp. 273-291. doi:10.1016/j.jenvp.2005.08.002

[27] R. B. Cialdini, "Crafting Normative Message to Protect the Environment," Current Directions in Psychological Science, Vol. 12, No. 4, 2003, pp. 105-109. doi:10.1111/1467-8721.01242

[28] P. W. Schultz, J. M. Nolan, R. B. Cialdini, N. J. Goldstein and V. Griskevicius, "The Constructive, Destructive, and Reconstructive Power of Social Norms," Psychology Science, Vol. 18, No. 5, 2007, pp. 429-434.

[29] J. M. Nolan, P. W. Schultz, R. Cialdini, N. J. Goldstein and V. Griskevicius, "Normative Social Influence Is Underdetected," Personality and Social Psychology Bulletin, Vol. 34, No. 7, 2008, pp. 913-923. doi:10.1177/0146167208316691

[30] S. Barr, "Strategies for Sustainability: Citizens and Responsible Environmental Behaviour,” Area, Vol. 35, No. 3, 2003, pp. 227-240. doi:10.1111/1475-4762.00172

[31] K. Chan, "Mass Communication and Pro-Environmental Behavior: Waste Recycling in Hong Kong," Journal of Environmental Management, Vol. 52, No. 4, 1998, pp. 317-325. doi:10.1006/jema.1998.0189

[32] L. Whitmarsh, "Behavioural Responses to Climate Change: Asymmetry of Intentions and Impacts," Journal of Environmental Information Science, Vol. 29, No. 1, 2009, pp. 13-23.

[33] L. M. Hunter, A. Hatch and A. Johnson, "Cross-National Gender Variation in Environmental Behaviors,” Social Science Quarterly, Vol. 85, No. 3, 2004, pp. 677-694. doi:10.1111/j.0038-4941.2004.00239.x 